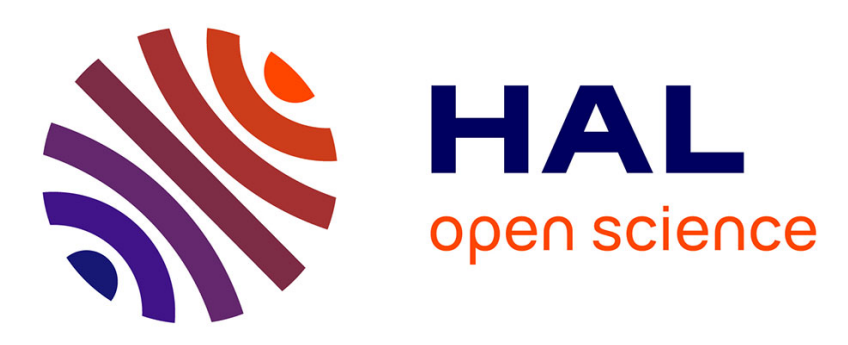

\title{
Direct selection on allozymes is not required to explain heterogeneity among marker loci across a Mytilus hybrid zone
}

N Bierne, C Daguin, François Bonhomme, Patrice David, Philippe Borsa

\section{To cite this version:}

N Bierne, C Daguin, François Bonhomme, Patrice David, Philippe Borsa. Direct selection on allozymes is not required to explain heterogeneity among marker loci across a Mytilus hybrid zone. Molecular Ecology, 2003, 12, pp.2505-2510. 10.1046/j.1365-294X.2003.01936.x . ird-01260447

\section{HAL Id: ird-01260447 \\ https://hal.ird.fr/ird-01260447}

Submitted on 22 Jan 2016

HAL is a multi-disciplinary open access archive for the deposit and dissemination of scientific research documents, whether they are published or not. The documents may come from teaching and research institutions in France or abroad, or from public or private research centers.
L'archive ouverte pluridisciplinaire HAL, est destinée au dépôt et à la diffusion de documents scientifiques de niveau recherche, publiés ou non, émanant des établissements d'enseignement et de recherche français ou étrangers, des laboratoires publics ou privés. 


\title{
Direct selection on allozymes is not required to explain heterogeneity among marker loci across a Mytilus hybrid zone
}

\author{
N. BIERNE,* C. DAGUIN,*『 F. BONHOMME,* P. DAVID $†$ and P. BORSA* $\ddagger$
}

\author{
* Laboratoire Génome, Populations, Interactions, Adaptation; UMR5000 Université Montpellier II - IFREMER - \\ CNRS, Station Méditerranéenne de l'Environnement Littoral, 34200 Sète, France; \\ † Centre d'Ecologie Fonctionnelle et Evolutive — CNRS, 34293 Montpellier cedex 5, France; \\ $\ddagger$ Institut de Recherche pour le Développement, UR081, BP A5, 98848 Nouméa cedex, Nouvelle-Calédonie \\ \Present address: UMR7127 CNRS — Université Paris 6, Station biologique de Roscoff, 29682 Roscoff cedex France \\ Correspondence: Nicolas Bierne.Fax: + 33 (0)4 674633 99,E-mail:n-bierne@univ-montp2.fr
}

\begin{abstract}
Unequal differentiation between two types of loci (allozyme and DNA markers) across a Mytilus hybrid zone has recently been claimed as evidence for direct selection on some llozyme loci. We provide here a counter-example: a noncoding DNA locus that exhibits as much differentiation as the incriminated allozymes do. The levels of genetic differentiation varied widely among both allozymes and noncoding DNA markers and no clear difference emerged between the two types of markers. This suggests that the strong interlocus variance in genetic differentiation has been confounded with a discrepancy between marker types as a result of an insufficient and unbalanced locus sampling. Heterogeneity in differentiation among neutral loci can be created by stochastic variance during the allopatric divergence preceding a secondary contact. In hybrid zones, a further source of variance is differential introgression among chromosomal regions after the secondary contact owing to the local influence of selected genes on more or less distant markers. However, the degree of differentiation alone gives no way to distinguish indirect pseudo-selection (a regular and ubiquitous feature of hybrid zones) from direct selection. More generally, we suggest that comparative neutrality tests based on discrepancies among marker types have to be applied with caution when the presence of semi-permeable genetic barriers to gene exchange is suspected.
\end{abstract}

Keywords: allozymes, hybrid zones, introgression, Mytilus, neutral hypothesis, selection

\section{Introduction}

The status of allozyme markers with regard to natural selection has long been debated (Eanes 1999). To infer selection on allozymes, an approach is to use a neutral control on which direct selection is very unlikely. Non-coding DNA markers have provided such neutral controls for at least the last decade and the comparison of geographical variation at allozymes and DNA markers has become a test of the neutral 
status of allozymes (McDonald 1994). However, such tests are often crippled by an insufficient number of loci or by unbalanced sampling regarding the two types of loci. Neutral loci may differ greatly in their amount of differentiation across a barrier to gene flow. It is common knowledge that drift itself generates a large stochastic variance in the degree of differentiation between two allopatric populations. When secondary contacts occur, gene flow can be restrained by partial genetic isolation, whose effect is twofold. Firstly, it delays the homogenization process, exactly as a physical barrier would do (Barton 1986), which increases the chance of observing remnants of the initial variance in differentiation acquired in allopatry. Secondly, it can accentuate heterogeneity among neutral loci because of differential introgression rates (Barton \& Hewitt 1985; Harrison 1990). Indeed, according to the theory of hybrid zones, the genes directly involved in reproductive isolation will form stable clines, while the homogenization of neutral markers is slowed down in proportion to their linkage disequilibrium with the former (Barton 1986). Introgression rates at neutral markers therefore often vary according to their physical linkage with selected genes, as can be observed in sunflower species for instance (Rieseberg et al. 1999). Riginos et al. (2002) compiled data on allele frequency differences at five allozyme loci, a mtDNA locus and four nuclear DNA loci, between a Mytilus edulis population of the Skagerrak (North Sea) and a M. trossulus population of the Baltic Sea. These authors contrasted the five non-allozyme markers, which showed relatively little differentiation, to the five, much more differentiated, allozyme loci. This was interpreted as evidence of selection on the five allozyme loci. Here, we expanded the genetic dataset on mussels from Baltic-Sea and Skagerrak sites by adding two noncoding nuclear markers, mac-1 (Daguin et al. 2001) and EFbis (Bierne et al. 2003). Also, we took into account all 18 allozyme loci examined in mussel samples from the Øresund hybrid zone area (Bulnheim \& Gosling 1988; Väinölä \& Hvilsom 1991). We conclude that: (i) a continuum in the degree of differentiation exists among loci within both the allozyme and nonallozyme markers; (ii) there was no statistical evidence that the ranges of differentiation differed between marker types; (iii) the five allozymes used by Riginos et al. (2002) are a biased sample of allozymes which only represents the upper range of the distribution. Therefore the conclusion of direct selection on allozymes is unwarranted. We instead propose, as did Väinölä \& Hvilsom (1991), that the neutral hypothesis, which involves the stochasticity of drift and the heterogeneity in the rate of introgression is consistent with the data.

\section{Materials and methods}

Mytilus spp. adult individuals were collected in Flødevigen (Norway, Skagerrak) and Gdansk (Poland, Baltic Sea). We also used a sample from Helgoland (Germany, North Sea) as reference for M. edulis, and samples from Gaspésie (Canada, Atlantic Ocean) and Hog Island (Tomales Bay, California, eastern Pacific Ocean) as references for M. trossulus. North Sea and eastern Pacific mussels have traditionally been used as references for, respectively, M. edulis (Coustau et al. 1990; Daguin et al. 2001) and M.trossulus (Rawson \& Hilbish 1995; Borsaet al. 1999). Two intron-length polymorphic markers were used; mac-1 (Daguin et al. 2001) and EFbis (Bierne et al. 2003). These markers have first been developed for M. edulis and $M$. galloprovincialis but new primers have been designed from mac-1 sequences (M. Ohresser, unpublished data) to obtain more efficient PCR-amplifications in M. trossulus. We used the following primer pairs: a newly designed forward primer (5 '-GCTGTATTTCCATCAATTGTTGG-3') in association with the reverse primer of Daguin et al. (2001) for locus mac-1; Fbis-F (5'-ACAAGATGGACAATACCGAACCACC-3') and EFbis-R2 (5'-CCTTCTGGATTTCCATGAATCGG-3') for locus EFbis. Comparison among loci can be hampered by variation in diversity (McDonald 1994; Hedrick 1999), especially when the differentiation is strong as is often the case in hybrid zones. To circumvent this problem, pooling alleles has been recommended (McDonald 1994). Alleles at a single locus were therefore pooled into species-specific compound alleles according to their frequencies in samples from each species. Synthetic alleles at a locus, that were characteristic of $M$. edulis populations, were called $E$. To measure differentiation, we used the difference in $E$ allele frequencies, $\Delta p$ (Barton 2000), between the two populations considered. 
Homogeneity of allele frequencies between pairs of populations was tested by an exact test using the GENEPOP software (Raymond \& Rousset 1995).

\section{Results}

Allele frequencies at loci EFbis and mac-1 are given in Table 1. The electrophoresis method we used does not allow us to measure bands precisely and only a relative scale can be used. The nomenclature for EFbis size-alleles follows Bierne et al. (2003). We here describe a new major class of size-alleles we have named $\mathrm{Ti}$, that is around 100 base pairs (bp) smaller than the Ei class. T0 was the most frequent allele in our Baltic Sea, western Atlantic and eastern Pacific samples of Mytilus trossulus (Table 1). Other size-alleles were numbered consecutively by size, each increment presumably corresponding to one base pair. The nomenclature for mac-1 size-alleles was an extension of the one presented in Daguin et al. (2001). Locus EFbis was almost differentially fixed $(\Delta p>0.98 ; P<0.001)$ between eastern Pacific $M$. trossulus and North Sea $M$. edulis used as references for each species (Table 1). It was also almost diagnostic $(\Delta p=0.97 ; P<$ 0.001) between Baltic Sea M. trossulus and North Sea (Germany) M. edulis, but a remarkably high frequency of trossulus alleles $(60 \%)$ was found in $M$. edulis populations from Skagerrak. A similar pattern was observed for an allozyme locus, Aap, suspected to be under selection by Riginos et al. (2002). Aap was almost dagnostic $(\Delta p>0.95)$ between Baltic Sea M. trossulus and northern Atlantic (Iceland) M. edulis, but $M$. trossulus Aap alleles were found in the Skagerrak (17\%). The genetic structure observed at locus mac-1 was more complex. At this locus the $M$. edulis reference sample from the North Sea sharply differed from its $M$. trossulus equivalent, from the eastern Pacific $(\Delta p=0.87, P<0.001)$. However, inconsistencies were observed when using synthetic alleles assigned with these reference samples in the Skagerrak-Baltic Sea comparison. For instance, mac-1 allele $a 3$ was more frequent in the North Sea than in the eastern Pacific, but it was more frequent in the Baltic Sea than anywhere else (Table 1). This allele would be assigned as edulis using the sample from the eastern Pacific as reference for $M$. trossulus, and the conclusion would be that Baltic Sea M. trossulus populations carry an edulis allele at a higher frequency than Skagerrak M. edulis populations. Such a pattern is not only visible at locus mac-1 but also at some enzyme loci [e.g. allele 100 at locus $A p$ for the Tvärminne population in the Baltic Sea (McDonald \& Koehn 1988) compared with Skagerrak mussels (Varvio et al. 1988)]. It seems improbable that such alleles have introgressed into $M$. trossulus and then decreased by genetic drift in North Sea M. edulis populations to the point that allele frequencies are now reversed compared to the initial situation. More parsimoniously, we propose that eastern Pacific $M$. trossulus should not be considered as representative of the initial state of the conspecific European populations. This is illustrated by the strong genetic differentiation observed at loci EFbis and mac-1 between our $M$. trossulus samples from the northwestern Atlantic and reference eastern Pacific $M$. trossulus (EFbis: $\Delta p=0.37, P<0.001$; mac-1: $\Delta p=0.41, P<0.001$ ). This differentiation applies to alleles not found in $M$. edulis (e.g. allele EFbis-T-10). In conclusion, in the absence of valid reference samples, it seems hopeless to disentangle the effects of the initial state vs. the introgression that could have occurred after secondary contact in determining the current allelic composition of Baltic $M$. trossulus populations. Table 2 presents $\Delta p$ estimates between Skagerrak (M. edulis) and Baltic Sea (M. trossulus) populations, $\Delta p$ estimates between North Sea (M. edulis) and eastern Pacific (M. trossulus) populations and the frequencies of E compound alleles in Baltic Sea M. trossulus samples, across six nuclear DNA and 18 allozyme loci. The lack of data for less discriminative allozymes illustrates how four or five discriminating allozyme loci, which may well belong to the same linkage group (Beaumont 1994), have been consistently used in the Mytilus literature, neglecting the information given by other loci and therefore adding to the sampling bias we are attempting to point out in the present paper. No discrepancy between allozyme and nonallozyme markers was apparent from the results of the Skagerrak-Baltic Sea comparison presented in Table 2. First, the suggestion that all the nonallozyme markers exhibit large frequencies of $M$. edulis alleles into $M$. trossulus Baltic ea populations, allegedly because they are not under selection (Riginos et al. 2002), can now be refuted by one counterexample: that of locus EFbis for which the frequency of compound allele $E$ was 
as low as for the most extreme allozyme locus. Second, although the most discriminating markers were allozyme loci, one should notice that the allozymes screened (18) outnumbered the DNA markers (6). Actually, the least differentiated markers were also allozymes. Using the reasoning of Riginos et al. (2002), balancing selection should be suspected for the latter. In short, the final picture was a continuous gradient of differentiation, independent of marker type (Wilcoxon two-sample test, $P>0.10$ ).

\section{Discussion}

Variable rates of admixture and introgression characterize Mytilus spp. assemblages in western Europe (Skibinski et al. 1983; Väinölä \& Hvilsom 1991). The two mussel populations considered here are separated by a hybrid zone that features concordant narrow clines of allele frequencies (Väinölä \& Hvilsom 1991). Whatever the status of the allozymes screened, the strong linkage disequilibria observed within the zone (Väinölä \& Hvilsom 1991) suggest a strong barrier to neutral gene flow. Neutral DNA markers are also affected by the barrier, as shown by significant nonzero $\Delta p$-values across the Øresund (Table 2). The barrier to gene exchange therefore seems to be active at the scale of the whole genome. However, introgression does occur, at least for some markers (Väinölä \& Hvilsom 1991; Borsa et al. 1999). In such conditions, the cumulative effect of precontact differentiation variance and postcontact differential introgression rates can create strong heterogeneity among neutral loci (Harrison 1990). Of course one cannot exclude the possibility that some of the genes observed may be under selection: the most discriminative allozyme loci are possible candidates for disruptive selection, as are the less discriminative ones with regard to balancing selection. However, we have shown that allele-frequency differentials said to be typical of directly selected allozymes were also found in one noncoding DNA marker (EFbis). This is sufficient proof that variation at the five allozyme loci did not depart from the expectations for neutral loci, which are under indirect pseudo-selection through their linkage to loci involved in reproductive isolation. Moreover, it should be noted that none of the five allozyme loci suspected to be under direct selection were fully diagnostic between the two mussel species. Direct selection would have to take a very peculiar form to explain why favoured alleles did not reach fixation on either side of the hybrid zone. We are aware that selection at sites tightly linked to some markers (for example an exon of the EF1- $\alpha$ gene of which we scored an intron) is possible. However, linkage to a selected site and direct selection are different issues: the existence of indirect selection of variable intensity in various markers within a hybrid zone has been well established for decades (Barton \& Hewitt 1985), while it remains ground-breaking to demonstrate the direct action of selection on a polymorphism. Heterogeneity in the rate of differentiation across a hybrid zone has therefore been hastily interpreted as evidence of direct selection. Could the same misinterpretation have occurred in other studies? The case of the American oyster Crassostrea virginica in Florida is an instructive example. Direct selection on allozymes was claimed (Karl \& Avise 1992) but was subsequently re-evaluated (McDonald et al. 1996). Karl \& Avise (1992) found drastic differences in allele frequencies between the Gulf of Mexico and the Atlantic Ocean at four anonymous nuclear-DNA markers, whereas allozyme polymorphisms were said to be fairly uniform all along the same area (Buroker 1983). This led to the conclusion that allozymes were under balancing selection (Karl \& Avise 1992). However, the discrepancy among marker types disappeared when six more nuclear-DNA markers were added to the analysis of oysters from the same area (McDonald et al. 1996). The picture finally obtained instead was a gradient of differentiation without clear discrepancies between types of markers (see Table 2 of McDonald et al. 1996). Further analyses revealed that C. virginica population structure in Florida has the characteristics of a hybrid zone (Hare \& Avise 1996, 1998). Interestingly, geographical structures consistent with the presence of a hybrid zone have recently been described with microsatellite loci in the Atlantic cod, Gadus morbua (Nielsen et al. 2003) and the acorn barnacle, Semibalanus balanoides (Dufresne et al. 2002), two taxa where selection on some protein loci has previously been suspected (Gadus: Mork et al. 1985; Pogson et al. 1995; Semibalanus: Holm \& Bourget 1994; Schmidt \& Rand 1999). However, some evidences of selection were inferred from the analysis of geographical variation outside the hybrid zones, making the conclusion of direct selection more robust in 
these cases. Nonetheless, genetically differentiated entities have been recognized with neutral markers. Geographic and/or reproductive isolation must therefore have occurred in the past and is probably still operating. Under these circumstances the variance in neutral evolution can be much larger than predicted under the singlepopulation coalescence theory (Wakeley 2000; Irwin 2002; Hudson \& Turelli 2003), as it has recently been illustrated by strong heterogeneity in genealogical patterns across loci in the Drosophila pseudoobscura complex of species (Machado et al.2002). Even though some of the genetic markers used here and in other studies may eventually prove to be under direct selection, rejecting the neutral hypothesis based on discrepancies in geographical variation among loci is hazardous, especially in the case of hybrid zones. Because genetic barriers to gene exchange (i.e. hybrid zones) may remain undetected, heterogeneous levels of differentiation should always be interpreted with caution.

\section{Acknowledgements}

We thank D. Charlesworth, D. Hedgecock and two anonymous referees for insightful comments on the manuscript. This research was funded in part by IFREMER URM 16 to FB.

\section{References}

Barton NH (1986) The effects of linkage and density-dependant regulation on gene flow. Heredity, 57, $415-426$.

Barton NH (2000) Estimating multilocus linkage disequilibria. Heredity, 84, 373-389.

Barton NH, Hewitt GM (1985) Analysis of hybrid zones. Annual Review of Ecology and Systematics, 16, 113148.

Beaumont AR (1994) Linkage study in Mytilus edulis, the mussel. Heredity, 72, 557-562.

Bierne N, Borsa P, Daguin C, Jollivet D, Viard F, Bonhomme F, David P (2003) Introgression patterns in the mosaic hybrid zone between Mytilus edulis and M. galloprovincialis. Molecular Ecology, 12, 447-462.

Borsa P, Daguin C, Ramos Caetano S, Bonhomme F (1999) Nuclear-DNA evidence that northeastern Atlantic Mytilus trossulus carry M. edulis genes. Journal of Molluscan Studies, 65, 524-527.

Bulnheim HP, Gosling E (1988) Population genetic structure of mussels from the Baltic Sea. Helgoländer Meeresunters, 42, 113-129.

Buroker NE (1983) Population genetics of the American oyster Crassostrea vinginica along the Atlantic coast and the Gulf of Mexico. Marine Biology, 75, 99-112.

Daguin C, Bonhomme F, Borsa P (2001) The zone of sympatry and hybridization of Mytilus edulis and M. galloprovincialis, as described by intron length polymorphism at locus mac-1. Heredity, 86, 342-354.

Dufresne F, Bourget E, Bernatchez L (2002) Differential patterns of spatial divergence in microsatellite and allozyme alleles: further evidence for locus-specific selection in the acorn barnacle, Semibalanus balanoides? Molecular Ecology, 11, 113-123.

Eanes WF (1999) Analysis of selection on enzyme polymorphism. Annual Review of Ecology and Systematics, 30, 301-326.

Hare MP, Avise JC (1996) Molecular genetic analysis of a steppedmultilocus cline in the american oyster. Evolution, 50, 2305-2315.

Hare MP, Avise JC (1998) Population structure in the American oyster as inferred by nuclear gene genealogies. Molecular Biologyand Evolution, 15, 119-128.

Harrison RG (1990) Hybrid zones: windows on evolutionary processes. Oxford Surveys in Evolutionary Biology, 7, 69-128.

Hedrick PW (1999) Highly variable loci and their interpretation in evolution and conservation. Evolution, 53, 313-318. 
Holm ER, Bourget E (1994) Selection and population genetic structure of the barnacle Semibalanus balanoides in the North Atlantic and Gulf of St. Lawrence. Marine Ecology Progressive Series, 113, 247-256.

Hudson RR, Turelli M (2003) Stochasticity overrules the 'threetimes rule': genetic drift, genetic draft, and coalescence times for nuclear loci versus mitochondrial DNA. Evolution, 57, 182-190.

Irwin DE (2002) Phylogeographic breaks without geographic barriers to gene flow. Evolution, 56, 23832394.

Karl SA, Avise JC (1992) Balancing selection at allozyme loci in oysters: implications from nuclear RFLPs. Science, 256, 100-102.

Machado CA, Kliman RM, Markert JA, Hey J (2002) Inferring the history of speciation from multilocus DNA sequence data: the case of Drosophila pseudoobscura and close relatives. Molecular Biology and Evolution, 19, 472-488.

McDonald JH (1994) Detecting natural selection by comparing geographic variation in protein and DNA polymorphisms. In: Non-Neutral Evolution: Theories and Molecular Data (ed. Golding B), pp. 88-100. Chapman \& Hall, New York.

McDonald JH, Koehn RK (1988) The mussels Mytilus galloprovincialis and M. trossulus on the Pacific coast of North America. Marine Biology, 99, 111-118.

McDonald JH, Verrelli BC, Geyer LB (1996) Lack of geographic variation in anonymous nuclear polymorphisms in the American oyster, Crassostrea virginica. Molecular Biology and Evolution, 13, 1114 1118.

Mork J, Ryman N, Ståhl G, Utter F, Sundnes G (1985) Genetic variation in Atlantic cod (Gadus morbua) throughout its range. Canadian Journal of Fisheries and Aquatic Sciences, 42, 1580-1587.

Nielsen EE, Hansen MM, Ruzzante DE, Meldrup D, Grønkjær P (2003) Evidence of a hybrid-zone in Atlantic cod (Gadus morbua) in the Baltic and the Danish Belt Sea revealed by individual admixture analysis. Molecular Ecology, 12, 1497-1508.

Pogson GH, Mesa KA, Boutilier RG (1995) Genetic population structure and gene flow in the Atlantic cod Gadus morbua: a comparison of allozyme and nuclear RFLP loci. Genetics, 139, 375-385.

Rawson PD, Hilbish TJ (1995) Evolutionary relationships among the male and female mtDNA lineages in the Mytilus edulis species complex. Molecular Biology and Evolution, 12, 893-901.

Raymond M, Rousset F (1995) GENEPOP (ver. 1.2): a population genetics software for exact test and ecumenicism. Journal of Heredity, 86, 248-249.

Rieseberg LH, Whitton J, Gardner K (1999) Hybrid zones and the genetic architecture of a barrier to gene flow between two sunflower species. Genetics, 152, 713-727.

Riginos C, Sukhdeo K, Cunningham CW (2002) Evidence for selection at multiple allozyme loci across a mussel hybrid zone. Molecular Biology and Evolution, 19, 347-351.

Schmidt PS, Rand DM (1999) Intertidal microhabitat and selection at Mpi: interlocus contrasts in the northern acorn barnacle, Semibalanus balanoides. Evolution, 53, 135-146.

Skibinski DOF, Beardmore JA, Cross TF (1983) Aspects of the population genetics of Mytilus (Mytilidae; mollusca) in the British Isles. Biological Journal of the Linnean Society, 19, 137-183.

Väinölä R, Hvilsom MM (1991) Genetic divergence and a hybrid zone between Baltic and North Sea Mytilus populations. Biological Journal of the Linnean Society, 43, 127-148.

Varvio SL, Koehn RK, Väinölä R (1988) Evolutionary genetics of the Mytilus edulis complex in the North Atlantic region. Marine Biology, 98, 51-60.

Wakeley J (2000) The effects of subdivision on the genetic divergence of populations and species. Evolution, 54, 1092-1101.

All co-authors have interest in the population genetics and evolution of marine organisms. This study was a by-product of a project aimed at examining the biogeography and the structure of genetic barriers to gene flow in the Mytilus edulis complex of species. 
Table 1 Allelic frequencies at nuclear-DNA loci EFbis and mac-1 in Mytilus edulis and M. trossulus; frequency of $M$. edulis compound allele (E) given for each population in bold; $N$, sample size

\begin{tabular}{|c|c|c|c|c|c|c|}
\hline Locus & Allele & $\begin{array}{l}\text { North Sea } \\
\text { Helgoland } \\
\text { (edulis) } \\
\end{array}$ & $\begin{array}{l}\text { Skagerrak } \\
\text { Flødevigen } \\
\text { (edulis) }\end{array}$ & $\begin{array}{l}\text { Baltic } \\
\text { Gdansk } \\
\text { (trossulus) } \\
\end{array}$ & $\begin{array}{l}\text { Atlantic } \\
\text { Gaspésie } \\
\text { (trossulus) } \\
\end{array}$ & $\begin{array}{l}\text { Pacific } \\
\text { Hog IIland } \\
\text { (trossulus) }\end{array}$ \\
\hline \multirow[t]{15}{*}{ EFbis } & $(\mathrm{N})$ & (38) & $(48)$ & (55) & $(48)$ & $(40)$ \\
\hline & EO & 0.97 & 0.38 & 0.01 & - & - \\
\hline & E-1 & - & 0.01 & - & - & - \\
\hline & E-2 & 0.01 & - & - & - & - \\
\hline & G2 & - & 0.01 & - & - & - \\
\hline & T5 & - & - & 0.01 & - & - \\
\hline & T4 & - & - & 0.01 & - & - \\
\hline & T2 & - & - & - & 0.05 & - \\
\hline & TO & 0.02 & 0.60 & 0.95 & 0.83 & 0.55 \\
\hline & $T-1$ & - & - & 0.01 & 0.01 & - \\
\hline & $T-7$ & - & - & - & - & 0.02 \\
\hline & $T-10$ & - & - & 0.01 & 0.08 & 0.43 \\
\hline & $T-12$ & - & - & - & 0.01 & - \\
\hline & $T-13$ & - & - & - & 0.01 & - \\
\hline & $E$ & 0.98 & 0.40 & 0.01 & 0.00 & 0.00 \\
\hline \multirow[t]{22}{*}{ mac-1 } & $(\mathrm{N})$ & (67) & (47) & (47) & (44) & (31) \\
\hline & t9 (T) & - & - & - & 0.01 & - \\
\hline & $18(T)$ & - & - & - & 0.02 & - \\
\hline & $t 7(T)$ & - & - & - & 0.03 & 0.04 \\
\hline & $16(T)$ & - & - & - & - & 0.02 \\
\hline & $t 1(T)$ & - & - & 0.21 & 0.11 & 0.20 \\
\hline & $t 2(T)$ & - & - & 0.10 & 0.25 & 0.41 \\
\hline & $13(T)$ & - & - & 0.03 & 0.08 & 0.15 \\
\hline & $t 4(T)$ & - & - & - & - & 0.02 \\
\hline & $15(T)$ & - & - & - & 0.01 & 0.02 \\
\hline & $c 4(E)$ & 0.04 & 0.05 & - & - & - \\
\hline & $a 0.4(T)$ & - & - & - & 0.01 & - \\
\hline & $a 0$ (E) & - & 0.02 & - & - & - \\
\hline & a1 (E) & 0.01 & 0.06 & - & - & - \\
\hline & a2 (E) & 0.20 & 0.10 & - & - & - \\
\hline & a3(T) & 0.25 & 0.28 & 0.47 & 0.28 & 0.13 \\
\hline & $a 4(T)$ & 0.01 & 0.07 & 0.07 & 0.08 & - \\
\hline & as (E) & 0.48 & 0.39 & 0.12 & 0.10 & - \\
\hline & as (T) & - & - & - & - & 0.03 \\
\hline & a9 (E) & 0.01 & 0.01 & - & - & - \\
\hline & $d(E)$ & - & 0.01 & - & - & - \\
\hline & $E$ & 0.74 & 0.64 & 0.12 & 0.10 & 0.00 \\
\hline
\end{tabular}


Table 2 Frequency of compound Mytilus edulis allele $(E)$ in Baltic mussels and relative difference in allele frequency, $\Delta p$, calculated between Skagerrak $M$. edulis and Baltic Sea M. trossulus and between North Sea $M$. edulis and eastern Pacific $M$. trossulus (in brackets: $\Delta p$-value for the northern Atlantic -Baltic Sea comparison). Loci were classed by type (nuclear-DNA vs. allozyme) and ranked by increasing $\Delta p$ (Skagerrak-Baltic comparison); bold type, allozyme loci previously suspected to be under direct selection; $N D$, no data

\begin{tabular}{lllll}
\hline Locus & $\begin{array}{l}\text { E Frequency } \\
\text { in Baltic Sea }\end{array}$ & $\begin{array}{l}\Delta p \\
\text { Skagerrak-Baltic }\end{array}$ & $\begin{array}{l}\Delta p \\
\text { North Sea-Pacific }\end{array}$ & Reference \\
\hline DNA markers & & & & \\
PLIIa & 0.72 & ND & ND & $(1)$ \\
ITS & 0.70 & ND & ND & $(1)$ \\
MAL-1 & 0.37 & ND & ND & $(1)$ \\
Glu-5' & 0.52 & 0.48 & 1.00 & $(2)$ \\
mac-1 & 0.12 & 0.53 & 0.87 & $(3)$ \\
EFbis & 0.01 & $0.39(0.97)$ & 0.98 & $(3)$ \\
Allozymes & & & & \\
Ark & 0.13 & 0.03 & ND & $(4)$ \\
Pgk & 0.02 & 0.06 & ND & $(4)$ \\
Me-1 & 0.06 & 0.07 & ND & $(4)$ \\
Ap & 0.17 & 0.08 & 0.18 & $(4)+(5)$ \\
Idh-2 & 0.83 & 0.08 & ND & $(4)$ \\
Aat-1 & 0.77 & 0.22 & ND & $(4)$ \\
Fdp & 0.57 & 0.42 & ND & $(4)$ \\
Ald & 0.05 & 0.45 & ND & $(4)$ \\
Aco-2 & 0.21 & 0.49 & ND & $(4)$ \\
Lap & 0.33 & 0.56 & 0.33 & $(4)+(5)$ \\
Idh-1 & 0.16 & 0.60 & ND & $(4)$ \\
Odh & 0.33 & 0.60 & 0.66 & $(4)+(5)$ \\
$\boldsymbol{G p i}$ & 0.03 & 0.78 & 0.56 & $(4)+(5)$ \\
Mpi & 0.11 & 0.82 & 1.00 & $(4)+(5)$ \\
$\boldsymbol{A a p}$ & 0.00 & $0.83(0.95)$ & 0.77 & $(5)+(6)$ \\
$\boldsymbol{E} \boldsymbol{E s t - \boldsymbol { D }}$ & 0.03 & 0.87 & 0.96 & $(4)+(5)$ \\
$\boldsymbol{P g m}$ & 0.09 & 0.87 & 0.57 & $(4)+(5)$ \\
Aco-1 & 0.03 & 0.91 & ND & $(4)$ \\
\hline & & & &
\end{tabular}

(1) Riginos et al. (2002); (2) Borsa et al. (1999); (3) present study; (4) Väinölä \& Hvilsom (1991); (5) McDonald \& Koehn (1988); (6) Bulnheim \& Gosling (1988). 